\begin{tabular}{|c|c|}
\hline \multirow{3}{*}{ 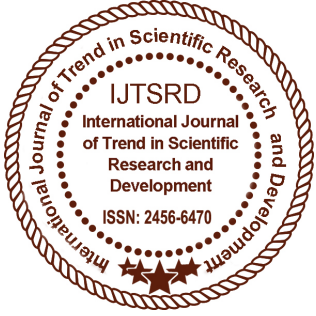 } & $\begin{array}{l}\text { International Journal of Trend in Scientific } \\
\text { Research and Development (IJTSRD) }\end{array}$ \\
\hline & International Open Access Journal \\
\hline & ISSN No: 2456 - 6470 | www.ijtsrd.com | Volume - 2 | Issue - 5 \\
\hline
\end{tabular}

\title{
Unified Power Quality Conditioner (UPQC) Using Power Conditioner Apply to 3 Phase 3 Wire System by Using Hysterisis and PLL
}

\author{
Miss. Anusha Swami Kadasi ${ }^{1}$, Mr. Nilesh M. Chamat ${ }^{2}$ \\ ${ }^{1}$ M.Tech Student, ${ }^{2}$ Assistant Professor \\ Electrical Power System, Ballarpur Institute of Technology, \\ Ballarpur, Chandrapur, Maharashtra, India
}

\begin{abstract}
The increasing demand of electric power is giving an emphasis on the need for the maximum utilization of renewable energy sources. On the other hand maintaining power quality to satisfaction of utility is an essential requirement. In this paper the design aspects of a Unified Power Quality Conditioner integrated with photovoltaic system in a distributed generation is presented. The proposed system consist of series inverter, shunt inverter are connected back to back on the dc side and share a common dc-link capacitor with Distributed Generation through a boost converter. The primary task of UPQC is to minimize grid voltage and load current disturbances along with reactive and harmonic power compensation. In addition to primary tasks of UPQC, other functionalities such as compensation of voltage interruption and active power transfer to the load and grid in both islanding and interconnected mode have been addressed. The simulation model is design in MATLAB/ Simulation environment and the results are in good agreement with the published work.
\end{abstract}

Keywords: Unified Power Quality Conditioner (UPQC), Power Quality Improvement, Distributed Generation (DG), MATLAB/Simulink.

\section{INTRODUCTION}

Power quality can be defined as any power problem faced in the frequency, current or voltage deviation which leads to mal-operation of the customer's equipment. It has been always difficult to maintain the quality of electric power so as to keep it within the acceptable limits. Mainly the use of power electronics devices that acts as the nonlinear load is responsible for the degradation in the poor power quality. Poor power quality results in various problems in the distribution systems like higher power losses, harmonics, sag and swells in the voltage, poor distortion and displacement factor. The recent developments in communications, digital electronics, and control system have rapidly increased the number of sensitive loads that require ideal sinusoidal supply voltage for their proper operation. So it became necessary to include some sort of compensation in order to meet limits proposed by standards. Here Unified power quality Conditioner (UPQC) has been used to overcome the power quality problem. UPQC which is a combination of back to back connected series and shunt APFs through a common DC link voltage, the two APFs function differently.

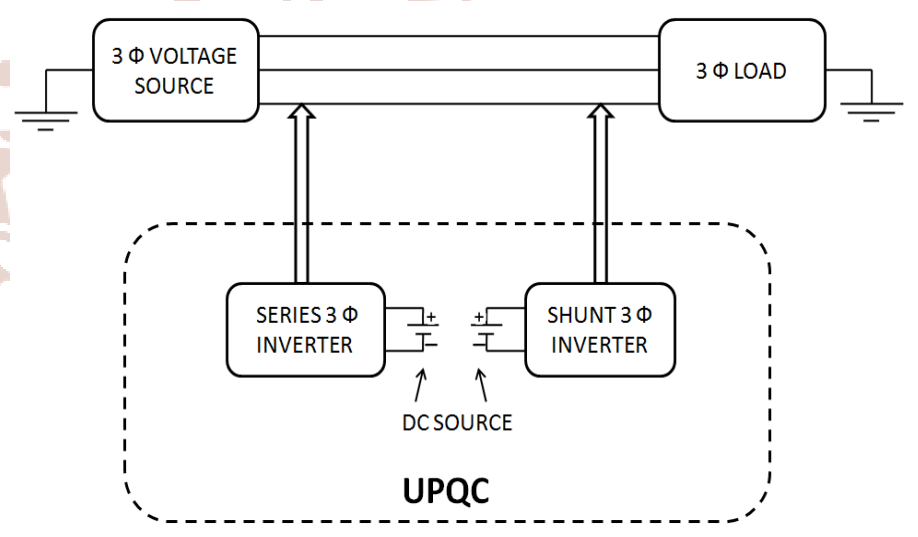

Fig. 1.Block diagram of system

The shunt active filter is mainly advantageous in removing the current related problems and the improvement of power factor and regulation of DC link voltage. Whereas the series APF helps in 
correction of voltage related problems by acting as a controlled voltage source. The voltage that is injected in series with the load by series Active Power filter is made to follow a control law which results in a sinusoidal load voltage that is the sum of the voltage injected by the series inverter and the input voltage. Whereas the shunt APF acts as a current source that injects a compensating harmonic current in order to have sinusoidal, in-phase input current. Several control strategies has been reported in literature that determines the reference values of the voltage and the current.

UPQC has the capability of compensating the harmonic current, reactive power; voltage imbalance and voltage sag and swell. It also helps in reducing the energy losses that happens in the power systems element and also increases the operation safety.

\section{NEED OF BETTER POWER QUALITY}

Power quality is becoming an important concern because of many reasons. Some major reasons are-

$>$ To increase the efficiency of power system many new devices such as shunt capacitors and adjustable-speed motor drives / are gaining popularity. These devices increase the harmonic level of the power system which increases the concern.

> Power electronic devices and loads that make use of control based on microprocessor and microcontroller based are more affected by power quality issues.

\section{SYSTEM CONFIGURATION}

\section{A. PLL}

Power quality instrumentation requires accurate fundamental frequency estimation and signal synchronization, even in the presence of both stationary and transient disturbances. In this paper, the authors present a synchronization technique for power quality instruments based on a single-phase software phase-locked loop (PLL), which is able to perform the synchronization, even in the presence of such disturbances. Moreover, PLL is able to detect the occurrence of a transient disturbance.

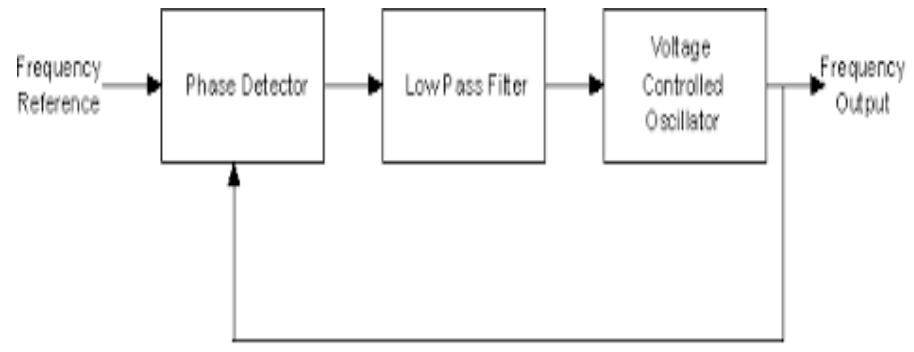

Fig. 2.PLL diagram

\section{B. HYSTERESIS CONTROLLER:}

Basic self-oscillating controllers based on hysteresis are well described in the literature. The hysteresis controller can be made with either a current- or a voltage loop. The benefits of hysteresis controllers are primarily the linear modulation caused by the saw tooth-shaped carrier with ideally straight slopes, and by the infinite power supply rejection ratio, PSRR, if the supply variation can be considered very slow compared to the switching frequency. Power supply variations at higher frequencies are not suppressed totally, and will result in sum and difference products of the reference signal and the power supply variation, but these still meets high suppression. For use in audio amplifier applications, the hysteresis controller is very desirable due to the high linearity and simple design. However, hysteresis controllers suffers from a switching frequency dependent on the modulation index, M, of the amplifier. All other basic types of self-oscillating modulators suffer from this phenomenon too.

\section{DISTRIBUTION GENERATION}

The DG refers to on-site power generation that is present near to the load and has less rating as compared to the central power station. It reduces the cost of transmission lines minimizes the voltage drop. Typically the size of such generators involved is 10 MW or less. Now-a-days, dispersed generators are also coming into picture which is still smaller in size typically $<500 \mathrm{KW}$. Optimal placement of DGs has been presented in, ensuring that the losses particularly the real power loss should be less thereby eliminating any sort of dips, swells or size in the normal voltage levels.

\section{Advantages of DG:}

An important factor to understand the issues related to DG is to recognize the different aspects on each and every point of consideration which may be illustrated with the benefits of DG from the following aspects.

1. End-user aspect: This is the most important aspect nowadays. It is greatly beneficial to those who require uninterrupted power, as these DGs act as an alternative in case of outages or power failures from main side. Another advantage is that the users can commercialize buy selling the extra power generated by their DGs provided the quality is maintained thereby providing power to inaccessible areas.

2. Distribution utility aspects: The Distribution Companies (DISCOMs) and Transmission 
International Journal of Trend in Scientific Research and Development (IJTSRD) ISSN: 2456-6470

Companies (TRANSCOMs) are generally interested to sell power through their transmission and distribution lines. But these DGs greatly reduce these costs. Even if with the increase in the demand of power with the increase in load, DGs, provides an alternative against unprecedented increase in load

\section{THREE PHASE INVERTER}

In the variable frequency drive rectifier paper, it explains how to go from three phase alternating current voltage to a direct current voltage by means of a rectifying circuit. The three phase bridge inverter with six diodes seemed a good starting point to convert $\mathrm{AC}$ to $\mathrm{DC}$. In this paper the opposite process is described. When a DC source (voltage or current) is available an inverter can be used to convert the energy to an AC source. When the source is a direct current source a current source inverter is needed, when it is a DC voltage source a constant or variable voltage source inverter can be used.

\section{CONTROL STRATEGY}

The proposed control strategy is aimed to generate reference signals for both shunt and series APFs of UPQC. In the following section, an approach based on UPQC technique is used to get reference voltage signals for the series APF, where as the control strategy for shunt APF is based on the combination of extended $\mathrm{p}-\mathrm{q}$ theory and desired reference signals of series APF., the supply voltage is distorted, a phase locked loop (PLL) is used to achieve synchronization with the supply voltage. The extraction of three-phase voltage reference signals for series APF is based on UPQCS generation, which is achieved using PLL.

\section{RESULT}

Performance studies of Shunt Active Filter under Sinusoidal current control strategy in grid integrated PV-Fuel Cell network has been simulated for a 3P3W system. The detailed control strategy of PV-FC hybrid system with grid integration is given in the figure 3 . The control circuitry for $3 \mathrm{P} 3 \mathrm{~W}$ is modeled for grid connected system.

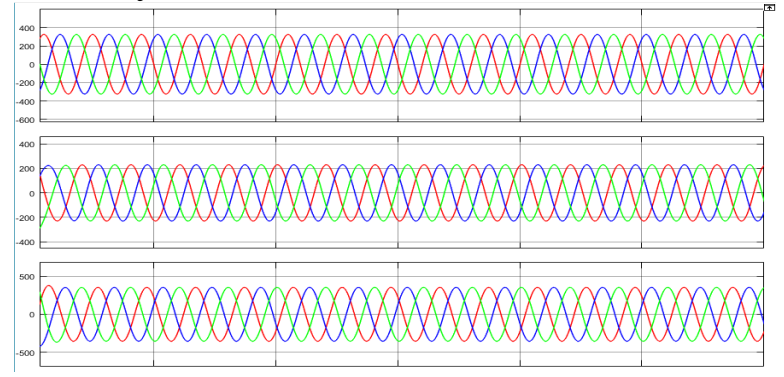

Fig. 3.Voltages

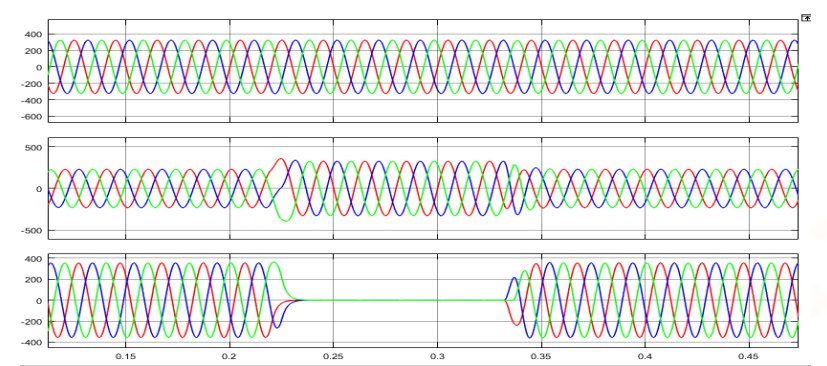

Fig.4. Overcome voltage

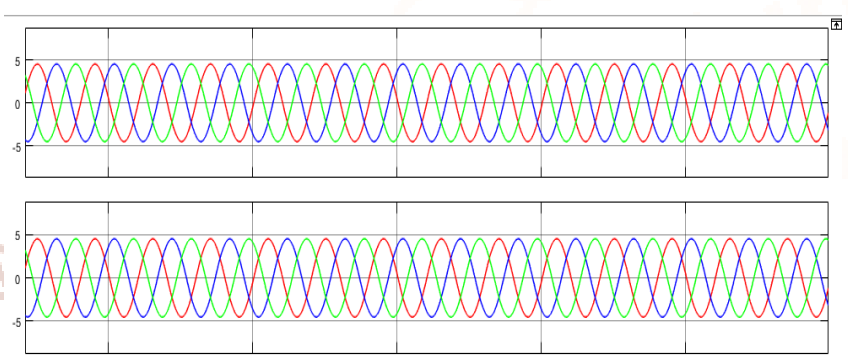

Figure 5: Current
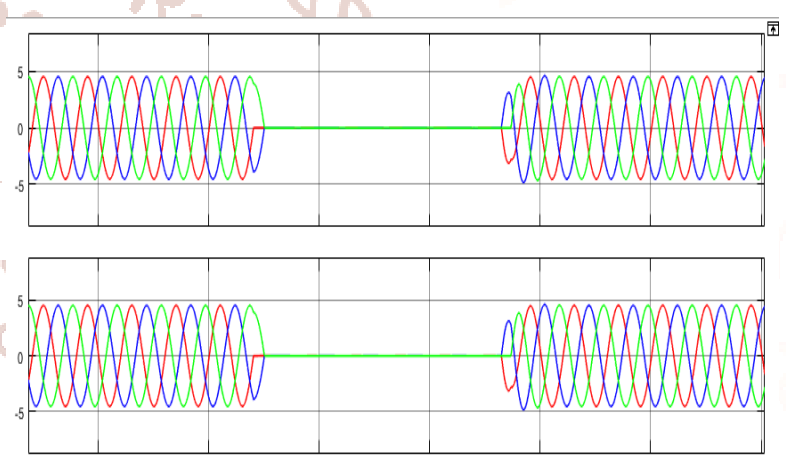

Fig.6. Overcome current

\section{CONCLUSION}

In this paper, the operation of UPQC was explained. A simplified control of UPQC that is relies on generation of unit vector templates and another method based on synchronous reference frame, P-Q control technique has been given for UPQC. Both of these methodologies provides effective solution for the improvement of power quality, solving the problems related with the power quality and helps in mitigation of voltage and current harmonics. Simulation of a Simulink based model has been done.

\section{REFERENCES}

1. Rudranarayan Senapati, Rajendra Narayan Senapati, Manoj Kumar Maharana "Study and Analysis of Performance of 3-Phase Shunt Active Filter in Grid-tied PV-Fuel Cell System Employing Sinusoidal Current Control Strategy" INTERNATIONAL JOURNAL of RENEWABLE ENERGY RESEARCH, Vol.8, No.1, March, 2018. 
2. Sarita Samal and Prakash Kumar Hota "Harmonics Mitigation of a Micro grid System using Modified SRF-UPQC Method" Indian Journal of Science and Technology, Vol 10(16), DOI: 10.17485/ijst/2017/v10i16/109990, April 2017.

3. Abhishek Singh1, A K Jhala2, Manish Prajapati "A Review on Unified Power Quality Conditioner for 3P4WSystem" (C) 2017, IRJET.

4. Lutfu Saribulut, Mehmet Tumay, and Dlyas Eker "Performance Analysis of Fuzzy Logic Based Unified Power Flow Controller" International Journal of Electronics and Communication Engineering Vol: 2, No:9, 2008.

5. Yash Pal1, A. Swarup, Bhim Singh "A Comparison of Three Topologies of Three Phase Four-Wire UPQC for Power Quality Improvement" 16th NATIONAL POWER SYSTEMS CONFERENCE, 15th-17th DECEMBER, 2010.

6. Rodrigo Augusto Modesto, Sérgio Augusto Oliveira da Silva Azauri Albano de Oliveira Júnior, and Vinícius Dário Bacon "Versatile Unified Power Quality Conditioner Applied to Three-Phase Four-Wire Distribution Systems Using a Dual Control Strategy" 10.1109/TPEL.2015.2487867, IEEE Transactions on Power Electronics TPEL-Reg-2015-060923.R1.

7. Jeno Paul, Ruban Deva Prakash, Jacob Raglend "Design and Simulation of Phase Locked Loop
Controller Based Three Phase Unified Power Quality Conditioner for Non linear and Voltage Sensitive Loads" INTERNATIONAL JOURNAL OF APPLIED ENGINEERING RESEARCH, DINDIGUL Volume 1, No 2, 2010.

8. Aparna B R, DR G C Shivasharanappa, Prof. Anguraja R, DR R Prakash "Unified Power Quality Conditioner (UPQC) in Alleviation of Power Quality Issues" International Journal of Scientific and Research Publications, Volume 6, Issue 8, August 2016.

9. P. Prasad, Md. Khaja Jainuddin, Y. Rambabu, V. K. R. Mohan Rao "Unified Power Quality Conditioner (UPQC) With Storage Device for Power Quality Problems" International Journal Of Engineering And Science Vol.3, Issue 8 (September 2013), PP 19-26.

10. Anagha R. Tembhurne, S. S. Dhamse "Power Quality Improvement using Unified Power Quality Conditioner with Distributed Generation" International Journal of Scientific \& Engineering Research, Volume 6, Issue 7, July-2015.

11. S. Thirukkovai, J. Venkatesan, Dr. S. M. Girirajkumar "Voltage Sag/Swell Mitigation Using UPQC" International Journal of Scientific \& Engineering Research, Volume 5, Issue 4, April-2014.

12. Vinod Khadkikar "Enhancing Electric Power Quality Using UPQC: A Comprehensive Overview" IEEE TRANSACTIONS ON POWER ELECTRONICS, VOL. 27, NO. 5, MAY 2012. 